\title{
Temporal dynamics of condition for estuarine fishes in their nursery habitats
}

\author{
R. W. Schloesser ${ }^{1,2, *}$, M. C. Fabrizio ${ }^{1}$ \\ ${ }^{1}$ Virginia Institute of Marine Science, College of William \& Mary, PO Box 1346, Gloucester Point, Virginia 23062, USA \\ ${ }^{2}$ Present address: Mote Marine Laboratory, 1600 Ken Thompson Parkway, Sarasota, Florida 34236, USA
}

\begin{abstract}
The condition of individuals in a year class may contribute to recruitment variability due to differential survival of poor- and well-conditioned fish, but the temporal dynamics of juvenile fish condition are poorly understood. We examined inter- and intra-annual dynamics of condition for juveniles of 3 species collected from estuarine nursery areas of Chesapeake Bay from November 2010 to June 2014. We describe temporal patterns in length-based indices, the hepatosomatic index (HSI), and relative subdermal lipid estimates for juvenile summer flounder Paralichthys dentatus $(\mathrm{n}=1771)$, Atlantic croaker Micropogonias undulatus $(\mathrm{n}=3911)$, and striped bass Morone saxatilis $(\mathrm{n}=874)$. Multiple indices provided a more complete understanding of energy-storage strategies for juveniles because temporal patterns among condition indices were not congruent for a given species. Most juvenile summer flounder and Atlantic croaker migrate from Chesapeake Bay in the fall, and both species exhibited increases in subdermal lipids in the time period prior to migration. For all species, individuals that remained in the estuary during winter exhibited high HSI values, indicating a common energy-storage strategy during winter. Mean condition of juveniles varied among year classes, but differences were inconsistent among indices, suggesting that energy was differentially stored among tissues for these year classes. Densitydependent effects contributed to variation in mean condition for summer flounder and striped bass. Our understanding of recruitment variability may be improved by assessing annual differences in mean condition as revealed by multiple indices.
\end{abstract}

KEY WORDS: Fulton's $K \cdot$ Hepatosomatic index · Subdermal lipid · Fish fatmeter · Juveniles · Bioenergetics $\cdot$ Recruitment

\section{INTRODUCTION}

In fishes, the number of individuals that recruit to the adult population is highly variable among years, and the strength of a year class is influenced by the survival of post-larval (juvenile) stages (Sissenwine 1984, Fogarty et al. 1991, Houde 2009). Survival of young fishes is affected by many factors, one of which is nutritional condition. Fish in poor condition may have lower survival rates than conspecifics in good condition. As such, condition of individual fish may play a critical role in recruitment variability. For

\footnotetext{
${ }^{*}$ Corresponding author: rschloesser@mote.org
}

example, lipid content, a measure of fish condition, is associated with improved survival during periods of reduced feeding activity, as seen in short-term (<1 mo) studies with larvae (Lochmann et al. 1995, Booth \& Alquezar 2002) and long term ( $>4 \mathrm{mo}$ ) studies with juveniles (Thompson et al. 1991, Simpkins et al. 2003). Feeding history and nutritional insufficiency (e.g. low lipid content) also influence survival in wild populations (Newsome \& Leduc 1975, Gardiner \& Geddes 1980, Wicker \& Johnson 1987). Although fish condition has been linked to survival, the use of condition indices to account for variation in

() The authors 2016. Open Access under Creative Commons by Attribution Licence. Use, distribution and reproduction are unrestricted. Authors and original publication must be credited. 
year-class strength has not been fully explored due in part to limited knowledge of the dynamics of juvenile fish condition. The purpose of our study was to examine condition dynamics for 3 species that inhabit estuarine nursery areas and relate the observed dynamics to their life-history strategies.

Individual fish condition may vary notably in response to the environmental challenges and behaviors imposed by a fish's life-history strategy. For example, life-history strategies of temperate marine fishes may include estuarine residency during winter (when fish may be exposed to environmental extremes) or migration to the continental shelf (Able \& Fahay 2010). Changes in condition of an individual may be manifested in different ways, depending on the energy-storage strategy used by a particular species and life stage. For instance, body weight may increase relative to length, or lipids may be preferentially stored in the liver or in subdermal tissues. Because a single condition index is not likely to reflect a variety of energy-storage strategies, we employed a suite of indices to describe condition dynamics: 2 length-based indices, the hepatosomatic index (HSI), and relative estimates of subdermal lipid obtained by using the Distell fish fatmeter (hereafter, 'fatmeter'). Length-based indices, such as Fulton's condition factor $\left(K_{i}\right.$ Ricker 1975) and relative condition $\left(K_{\mathrm{n}}\right.$ Le Cren 1951), assume that greater body mass at a given length reflects better condition (Anderson \& Neumann 1996, Froese 2006). The HSI refers to the ratio of liver mass to body mass, and is assumed to be a measure of condition because many fishes store lipids in their liver (Jensen 1979, Adams \& McLean 1985, Lambert \& Dutil 1997). The fatmeter uses lowpower microwaves to measure subdermal lipid content in a non-destructive manner (Kent 1990, Crossin \& Hinch 2005). In some fish species, subdermal lipid reserves are preferentially used to support migration (Leonard \& McCormick 1999).

Here, we investigated condition dynamics for juveniles of 3 species: summer flounder Paralichthys dentatus, Atlantic croaker Micropogonias undulatus, and striped bass Morone saxatilis during the time they occupy estuarine nursery areas in Virginia. These species represent disparate families with different life-history strategies, ecological niches, and degrees of estuarine residency (Able \& Fahay 2010), which may shape how individuals respond to environmental variability (Houde 1997). In the mid-Atlantic region, juvenile summer flounder and Atlantic croaker are facultative estuarine residents, and many individuals move offshore to the continental shelf as water temperatures decrease during fall (towards the end of their first year of life; Kraus \& Musick 2001, Miller et al. 2003). However, members of the midAtlantic populations of these species also reside in the Chesapeake Bay during winter as evidenced by their occurrence in long-term, monthly surveys of fish populations in the bay (authors' pers. obs.). The presence of a migratory and a resident contingent within a single population is a characteristic of a species that displays a partial migration strategy (Jonsson \& Jonsson 1993, Kerr et al. 2009). In some species, membership in the migratory or resident contingent is associated with differences in growth and bioenergetics (Jonsson \& Jonsson 1993, Kerr \& Secor 2009). Regardless of contingent membership, juvenile summer founder and Atlantic croaker must be well-conditioned to endure winter conditions in the estuary or undertake migration. Individuals in poor condition may suffer higher mortality rates during migration (Brodersen et al. 2008) or during winter (Thompson et al. 1991); therefore, they must build energy reserves prior to either undertaking longdistance movements (Rios et al. 2011) or residing in estuaries during winter. Unlike summer flounder and Atlantic croaker, striped bass remain in coastal tributaries during their first year of life (i.e. obligate estuarine residents). Juvenile striped bass can lose a large proportion of their energy and lipid reserves during winter, and winter mortality of juveniles has been demonstrated in mid-Atlantic estuaries (Hurst \& Conover 1998, 2003), suggesting that individual condition may be important for overwinter survival.

We examined 3 hypotheses concerning the condition of juvenile fishes: (1) multiple indices are required to capture condition dynamics for a species because indices do not exhibit similar intra-annual patterns; (2) species with similar life-history strategies exhibit similar condition dynamics; and (3) mean fish condition differs among years. Our approach focused on condition indices for estuarine residents during time periods prior to offshore migration and during winter. The dynamics among condition indices during these periods are expected to reflect variation in energy-storage strategies of juvenile summer flounder, Atlantic croaker, and striped bass. The amount of energy available to an individual for storage may vary among years, particularly due to differences in the density of conspecifics which may alter prey availability (Mittelbach 1988, Casini et al. 2006). Environmental conditions may also mediate energy allocation (Jobling 1994, Sogard \& Spencer 2004). Thus, to examine inter-annual variation in mean fish condition, we considered density-dependent and environmental effects on fish condition. 


\section{MATERIALS AND METHODS}

All fish capture, handling, and euthanasia procedures were approved by the College of William \& Mary Institutional Animal Care and Use Committee (protocols 2008-05-19-5360-mcfabr, 2010-07-206788-mcfabr, and 2011-06-06-7347-tdtuck) and followed all applicable state regulations and federal guidelines.

\section{Field collections}

Juvenile summer flounder $(\mathrm{n}=1771)$, Atlantic croaker $(\mathrm{n}=3911)$, and striped bass $(\mathrm{n}=874)$ were sampled monthly between November 2010 and June 2014 from Virginia's coastal waters (Fig. 1). Most samples were collected using a $9.14 \mathrm{~m}$ otter trawl in the Chesapeake Bay and the James, York, and Rappahannock Rivers, following random-stratified sampling protocols described by Tuckey \& Fabrizio (2015). Additionally, summer flounder and Atlantic croaker were collected from Mobjack Bay and a coastal lagoon near Oyster, Virginia (Fig. 1), using a $4.88 \mathrm{~m}$ otter trawl. For each species, we calculated local density (ind. $\mathrm{m}^{-2}$ ) by dividing the number of fish collected at a site by the area swept by the trawl. Temperature $\left({ }^{\circ} \mathrm{C}\right)$, salinity (psu), and dissolved oxygen $\left(\mathrm{mg} \mathrm{l}^{-1}\right)$ were measured near the bottom at each sampling site; depth (m) was also recorded. In the coastal lagoon, environmental conditions varied widely with tidal cycles, and therefore temperature, salinity, and dissolved oxygen were averaged on a daily basis. Following capture, individuals were immediately euthanized by immersion in an ice slurry and returned to the laboratory for condition measurements.

\section{Condition measurements}

In the laboratory, individuals were measured for length, subdermal lipids, body weight, and liver weight. Length was recorded to the nearest $\mathrm{mm}$. We examined condition indices for juvenile (i.e. age-0) summer flounder between 156 and $290 \mathrm{~mm}$ total length (TL), Atlantic croaker between 117 and $220 \mathrm{~mm} \mathrm{TL}$, and striped bass between 117 and $200 \mathrm{~mm}$ fork length (FL). Individuals were considered juveniles if they were smaller than monthly length thresholds described by Tuckey \& Fabrizio (2015).

Only fish large enough to appropriately sample with the fatmeter were considered in this analysis (R. W. Schloesser pers. obs.). Fatmeter (model FFM992) measurements were taken from the midline of the body behind the operculum. At this location, 4 measurements were taken from the non-eyed side of summer flounder $(\mathrm{n}=1770)$, both sides of Atlantic croaker ( $\mathrm{n}=3884)$, and the left side of striped bass ( $\mathrm{n}=874$ ), as readings from these locations exhibit significant positive correlation with energy content as measured by bomb calorimetry (Schloesser 2015). Measurements were averaged to assess relative subdermal lipid content of individual fish. The accuracy of the fatmeter varies and depends on lipid content of the sample: accuracy is $\pm 1.5 \%$ when lipid content is between 2 and $15 \% ; \pm 2.5 \%$ when lipid content is between 16 and $30 \%$; and $\pm 4 \%$ when lipid content is $>31 \%$ (Anonymous 2010).

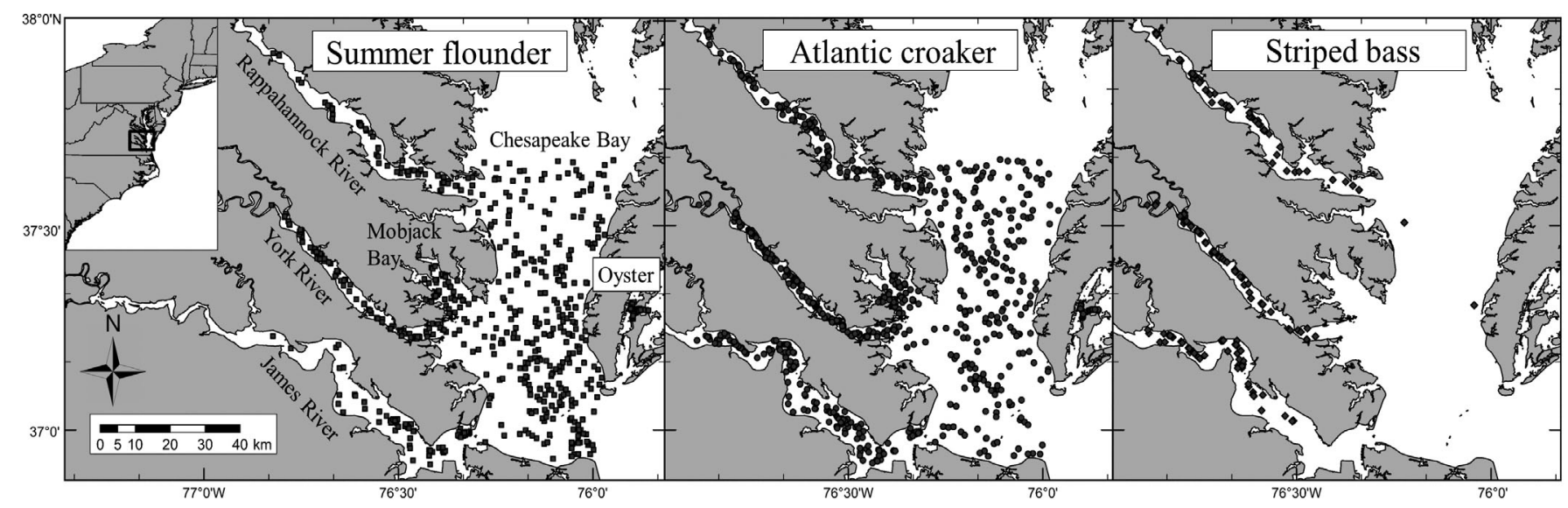

Fig. 1. Sampling locations in Virginia used to collect summer flounder Paralichthys dentatus, Atlantic croaker Micropogonias undulatus, and striped bass Morone saxatilis for analysis of temporal patterns in condition. 'Oyster' designates the sampling location in a coastal lagoon 
Body and liver mass were measured with a Mettler Toledo XA204 balance (accurate to $0.1 \mathrm{mg}$ ). Because some individuals were kept alive for other studies and some livers were degraded and could not be weighed accurately, the HSI was calculated for 1674 summer flounder, 3559 Atlantic croaker, and 776 striped bass as:

$$
\mathrm{HSI}=W_{\text {liver }} \times W^{-1} \times 100
$$

where $W_{\text {liver }}=$ wet mass of liver $(\mathrm{g})$ and $W=$ wet body mass (g) (Jensen 1979, Lambert \& Dutil 1997). Fulton's $K$ was calculated for all individuals as:

$$
K=W \times L^{-3} \times 10^{N}
$$

where $L=$ length $(\mathrm{mm})$, and $N=$ an integer to bring the value of $K$ near 1 (Ricker 1975). Relative condition factor $\left(K_{n}\right)$ was calculated for all individuals using:

$$
K_{\mathrm{n}}=W \times\left(a L^{b}\right)^{-1}
$$

where $a$ and $b$ are constants describing the allometric relationship for fish in a given population (Le Cren 1951). Constants were estimated using nonlinear least-squares modeling via the 'Nlin' procedure in SAS (v.9.3, SAS Institute) (Schloesser 2015). The length-based indices that best represent energy content as measured by bomb calorimetry for these species are $K$ for summer flounder and Atlantic croaker, and $K_{\mathrm{n}}$ for striped bass (Schloesser 2015); these length-based indices are therefore the focus of our analyses.

\section{Intra-annual patterns in condition}

We depicted intra-annual patterns in condition of juvenile fish that reside in Virginia estuaries using generalized additive models (GAMs). For each species, the GAM of condition adjusted for the effect of year class was:

$$
Y_{i j}=\mu+\alpha_{i}+g(\text { day })+\varepsilon_{i j}
$$

where $Y_{i j}=$ the condition of the $j$ th individual from the $i$ th year class as measured by length-based indices, HSI, or relative subdermal lipid estimates; $\mu=$ the intercept, representing the overall mean condition of individuals; $\alpha_{i}=$ the effect of the $i$ th year class; $g($ day $)=$ nonparametric smoothing function for ordinal day; and $\varepsilon_{i j}=$ the random unexplained error, assumed to be independent and normally distributed.

The GAM was fit using the GAM function in $\mathrm{R}(\mathrm{R}$ Core Team 2014). The degrees of freedom associated with fitting the smoothing function $(k)$ were chosen by identifying local minima in generalized cross validation $(\mathrm{gcv})$ scores ( $k$ was constrained to less than 10 to minimize over-fitting). Analyses of condition focused on one biological year beginning in June for summer flounder, May for Atlantic croaker, and October for striped bass.

\section{Temporal and density-dependent variation in condition}

We used a general linear mixed model approach to examine the effect of year class, density, and time (month) on mean condition of juvenile fishes as measured by length-based indices ( $K$ or $K_{n}$ ), HSI, and relative subdermal lipid estimates; we treated these effects as fixed effects in the model. Local density of conspecifics was included as a fixed factor in the models because inferences were made only on the range of observed densities, which may not be representative of densities in unsampled habitats within Virginia's estuaries. The interaction between local density and year class was examined in models for which interaction plots suggested the presence of an interaction. To address the potential added variation among year classes due to variation in fish size and environmental conditions, we included the following random effects in the model: the length of the individuals, and the salinity, dissolved oxygen, and depth at the sites where individuals were collected. Fish length and environmental factors were centered to reduce collinearity among predictors in the model. We considered including water temperature in the models, however, the collinearity between water temperature and month could not be removed through centering or standardizing (tolerance values remained <0.10). Because month is a proxy for multiple environmental effects that are not explicitly included in the model (e.g. prey availability), we retained month as a factor in the models and excluded water temperature. Fish length was excluded from the model for summer flounder subdermal lipid because the inclusion of fish length resulted in heterogeneous variances, and thereby violated a basic assumption of linear models. Subdermal lipid estimates for summer flounder and Atlantic croaker were square-root transformed and HSI values for striped bass were logtransformed because these transformations most suitably met the linear model assumption of homogeneous variances. Because we collected specimens from a random stratified sampling design each month, we minimized spatial bias in the temporal 
patterns of condition due to spatial variability in environmental conditions.

The global model describing mean fish condition was:

$$
Y_{i j k}=\mu+\alpha_{i}+\beta_{j}+\gamma+(\alpha \gamma)_{i}+\delta+\theta+\lambda+\tau+\varepsilon_{i j k}
$$

where $Y_{i j k}=$ the condition of the $k$ th individual from the $i$ th year class and the $j$ th month as measured by length-based indices, HSI, or relative subdermal lipid estimates; $\mu=$ the intercept, representing the overall mean condition of all individuals of a given species; $\alpha_{i}=$ the effect of the $i$ th year class; $\beta_{j}=$ the effect of the $j$ th month; $\gamma=$ the effect of local density; $(\alpha \gamma)_{i}=$ the effect of the interaction between year class and local density; $\delta=$ the effect of fish size (except for models for summer flounder); $\theta=$ the effect of dissolved oxygen concentration; $\lambda=$ the effect of depth; $\tau=$ the effect of salinity; and $\varepsilon_{i j k}=$ the random unexplained error, assumed to be independent and normally distributed.

We used the MIXED procedure in SAS v.9.3 to fit the global model and simpler models that omitted one or more factors. For some indices, a significant interaction between year class and local density suggested the effect of local density (i.e. fish captured in the same tow) on condition indices varied among years. Therefore, we modeled heterogeneity in the variances among year classes with the group option of the random statement in the MIXED procedure; this allowed us to take into account year-class specific variation in the effects of environmental conditions and fish size. We specified the Kenward-Roger method for calculating degrees of freedom due to the presence of multiple random effects (Kenward \& Roger 1997).

We used the approach of Littell et al. $(2002,2006)$ and Zuur et al. (2007) to guide model building. First, we identified the variance-covariance structure that best described the random variation in the data using restricted maximum likelihood (REML) estimation and Akaike's information criterion corrected for small sample size $\left(\mathrm{AIC}_{\mathrm{c} i}\right.$ Burnham \& Anderson 2002). The preliminary global model for each species and condition index included all fixed and random effects; both simple variance components and yearclass specific variance components were considered for preliminary models. Secondly, maximum likelihood (ML) estimation was used to fit models that considered various combinations of the fixed effects to describe juvenile fish condition. $\mathrm{AIC}_{\mathrm{c}}$ was used to identify the combination of effects that best described mean condition, such that we selected the simplest model within $2 \mathrm{AIC}_{\mathrm{c}}$ units of the lowest value (Burnham \& Anderson 2002). Third, we used REML estimation to fit the model identified in step 2, and used those parameter estimates to make inferences about the effect of year class, month, and local density on fish condition indices.

For some indices (HSI and subdermal lipids for summer flounder, and subdermal lipids for Atlantic croaker), the interaction between year class and local density was significant. In these cases, we examined year-class specific models and used $t$-tests to examine density effects on mean fish condition. The indices that did not exhibit a significant interaction effect included $K$ for summer flounder, $K$ and HSI for Atlantic croaker, and all striped bass condition indices; for these indices we report the significance of main effects (year class, month, and density) directly with $F$-tests. For the effect of year class on condition, we report least square means from the general linear mixed models because these model-based means are appropriately adjusted for the effect of density on mean condition in each year. Estimated mean condition indices for each year class were compared using the Tukey-Kramer method, which adjusts the significance level due to multiple comparisons; we used on overall $\alpha$ level of 0.05 .

To help interpret intra-annual patterns in mean condition of estuarine residents, we examined multiple a priori hypotheses concerning differences in mean condition among time periods; these hypotheses were tested using contrast statements, which are linear functions of parameter estimates from the general linear mixed models. Generally, time periods were identified as 2 or 3 consecutive months. For summer flounder, mean condition was compared among 4 time periods: summer (July-August), the period prior to peak migration (September-October), the period after peak migration (December-January), and winter (February-March). Note that condition measures during the peak migration month (November) were excluded from analyses. Similarly, mean condition of Atlantic croaker was examined in summer (June-July), the period prior to peak migration (August-September), the period after peak migration (November-December), and winter (January-March). Peak migration for Atlantic croaker occurred in October. Finally, mean condition of striped bass was examined among time periods representing early winter (November-December), late winter (FebruaryMarch), and spring (April-June). January was excluded from analyses of time periods due to variable environmental conditions that were dissimilar to early or late winter periods. Significance in all analyses was assessed at $\alpha=0.05$. 


\section{RESULTS}

\section{Intra-annual patterns in condition}

Assessment of fish condition depended on the index used to measure condition, the time of year, and the species considered. In general, for summer flounder, mean $K$ and HSI values declined through the summer and were significantly lower in the period prior to migration than during any other time period investigated (Fig. 2, Table 1). Mean subdermal lipid stores increased temporarily in the fall, notably in October, just prior to the period of peak migration (Fig. 2). Individuals that remained in Chesapeake Bay after the peak migration period had significantly lower mean subdermal lipids and significantly higher mean $K$ and HSI than what we observed prior to peak migration (Table 1). During winter, mean $K$ declined and mean HSI increased significantly (Fig. 2); furthermore, many individuals had HSI values greater than 1.5 units, levels not observed prior to peak migration (Fig. 3).

Juvenile Atlantic croaker exhibited similar temporal patterns in Fulton's $K$ and subdermal lipids
(Fig. 2). Mean values of these indices increased during the summer and were highest prior to the time when juvenile Atlantic croaker typically leave Chesapeake Bay (Fig. 2). Fulton's $K$ and subdermal lipids were significantly lower for individuals residing in the bay during winter than during most other times of the year (Table 1). Mean HSI values exhibited a pattern similar to that in summer flounder (Fig. 2), with mean values lower during the pre-migration period and significantly higher for individuals residing in Chesapeake Bay from November to March (Table 1).

Striped bass also exhibited high mean HSI values during winter (Fig. 2), and mean HSI values were significantly higher during late winter compared with early winter (Table 1). Mean HSI values then declined to significantly lower levels, presumably as fish resumed growth in the spring (Fig. 2). Mean subdermal lipid content was also significantly lower during the spring than during early or late winter. Patterns in mean $K_{\mathrm{n}}$ for striped bass were less apparent than for the other indices; $K_{\mathrm{n}}$ was variable over the time period investigated, and no significant differences were detected among time periods (Fig. 2, Table 1).
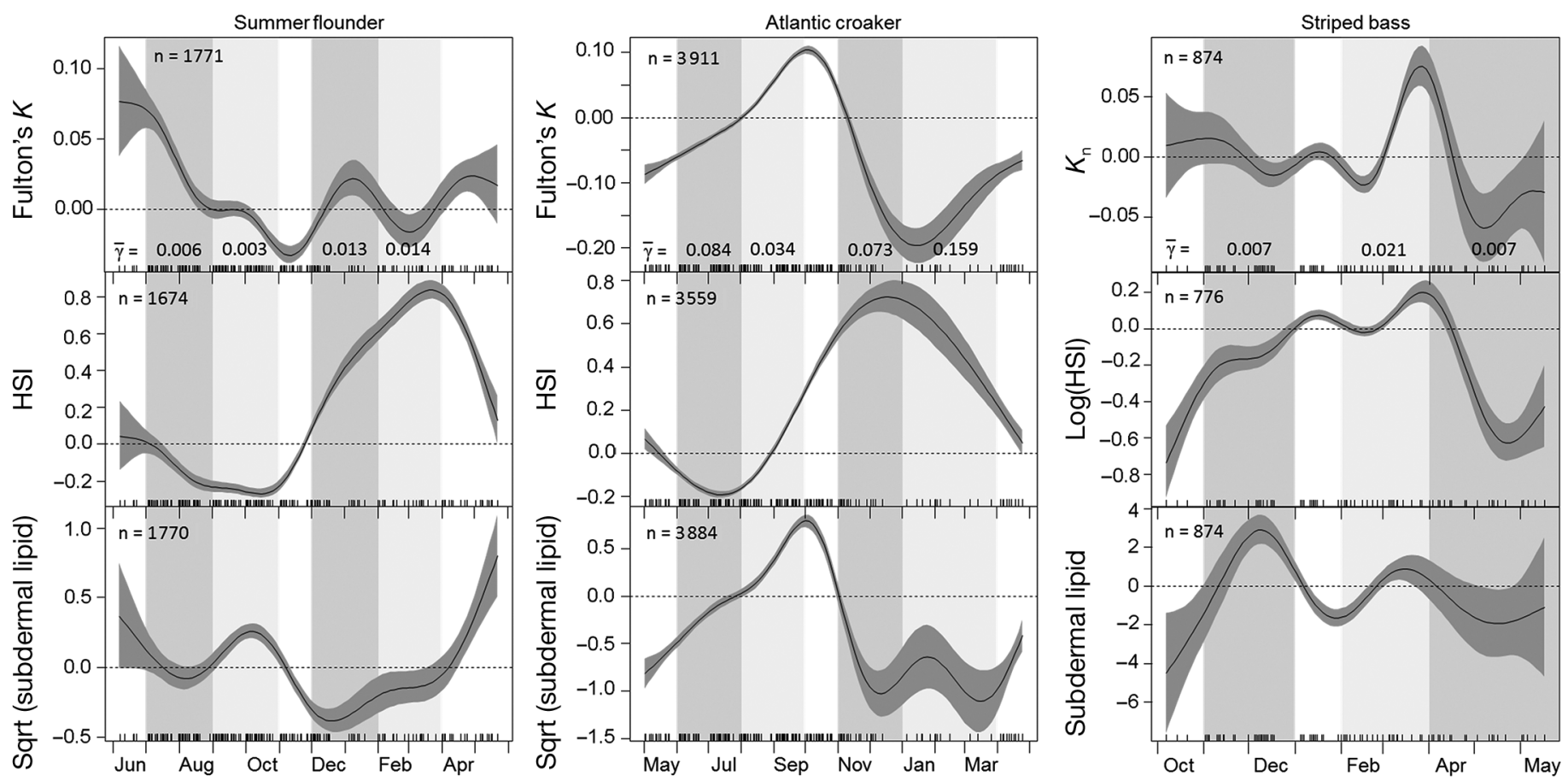

Fig. 2. Temporal dynamics of condition measured by length-based indices (Fulton's $K$ or relative condition $\left[K_{\mathrm{n}}\right]$ ), the hepatosomatic index (HSI), and relative subdermal lipid estimates measured by the fatmeter for juvenile summer flounder Paralichthys dentatus, Atlantic croaker Micropogonias undulatus, and striped bass Morone saxatilis. Hash marks along the $x$-axis indicate observed values. Solid line represents the smoothing function \pm 2 SE (dark grey shading) fitted by a generalized additive model. Shaded vertical bars denote time periods examined for differences in mean condition (Table 1), and $\bar{\gamma}$ is the mean local density (ind. $\mathrm{m}^{-2}$ ) of conspecifics for each time period. The dotted lines at 0 denote the mean condition for each year class, and therefore, the $y$-axis represents a deviation from that mean. Sqrt designates a square-root transformation 


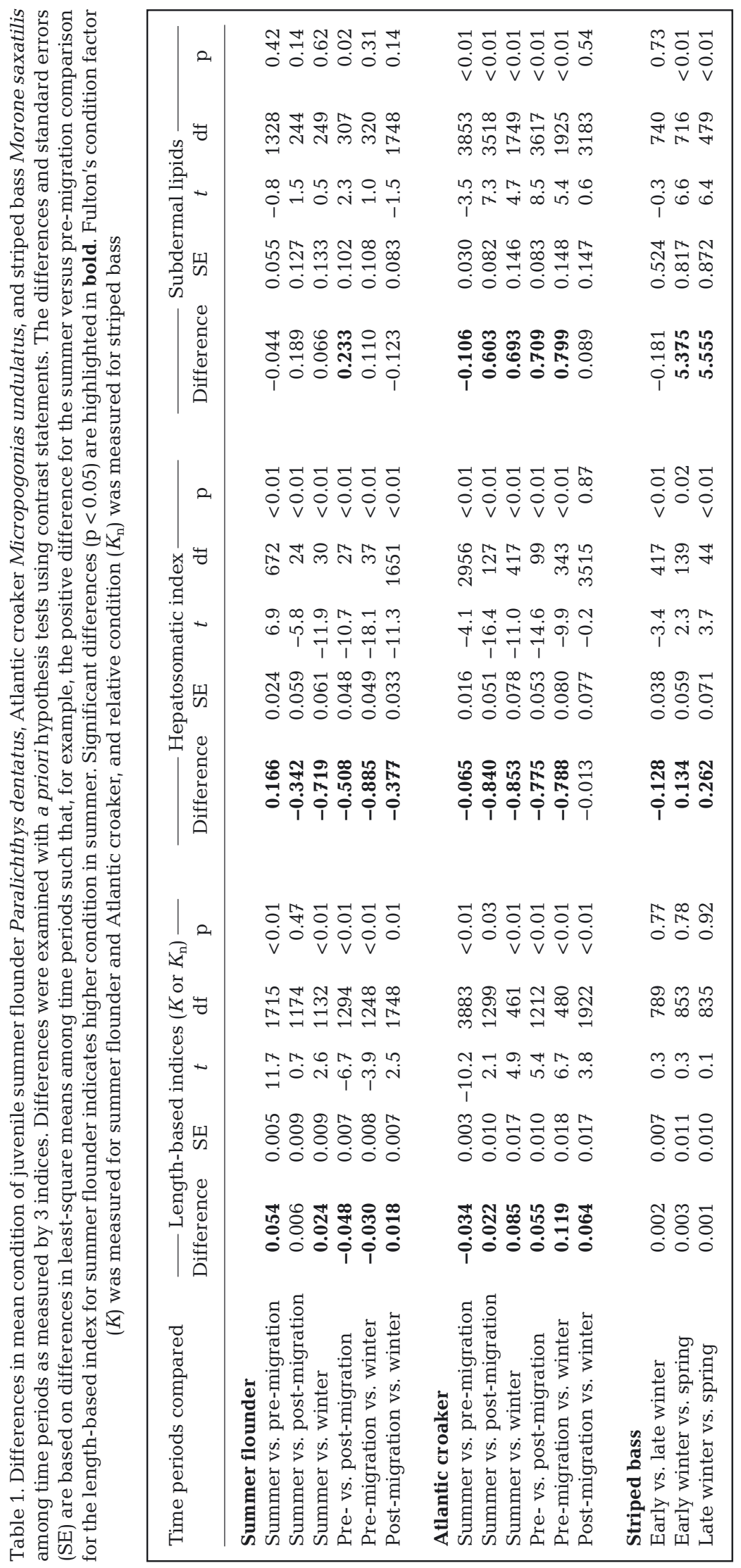

\section{Temporal and density-dependent variation in condition}

Mean condition of juvenile fish differed among years, but these differences were not consistent among indices (Fig. 4), indicating that energy was differentially stored among tissues for these year classes. The effect of local density on mean condition also varied by year, species, and in the manner in which condition was expressed (Tables 2 \& 3). In eastern Virginia, the period of 2010 to 2014 was characterized by unique environmental conditions that influenced the yearclass strength of these species and potentially mediated the effect of density on mean condition. In 2011, the cold winter (December-February) and wet spring (March-May) resulted in the highest observed recruitment for striped bass in Virginia waters since 1980 (Machut \& Fabrizio 2012), but a low abundance of Atlantic croaker and summer flounder (Tuckey \& Fabrizio 2015). Conversely, 2012 was characterized by a warm winter and a dry spring, resulting in strong year classes of Atlantic croaker and summer flounder (among the highest observed recruitments since 1988; Tuckey \& Fabrizio 2015), but a low abundance of striped bass. In general, 2010 (for striped bass only) and 2013 produced near-average year classes for these species. Because environmental conditions were not consistent among years, year-class specific variance components were useful in explaining the random variation in fish condition among years for all species; this approach improved model fit and allowed us to detect density and yearclass effects.

For juvenile summer flounder, the highly abundant 2012 year class exhibited the lowest mean condition, as measured by Fulton's $K$ and subdermal lipids (Fig. 4). The 2013 year class exhibited the highest degree of subdermal lipid storage (Figs. 3 \& 4), and the 2011 and 2013 year classes were comprised 

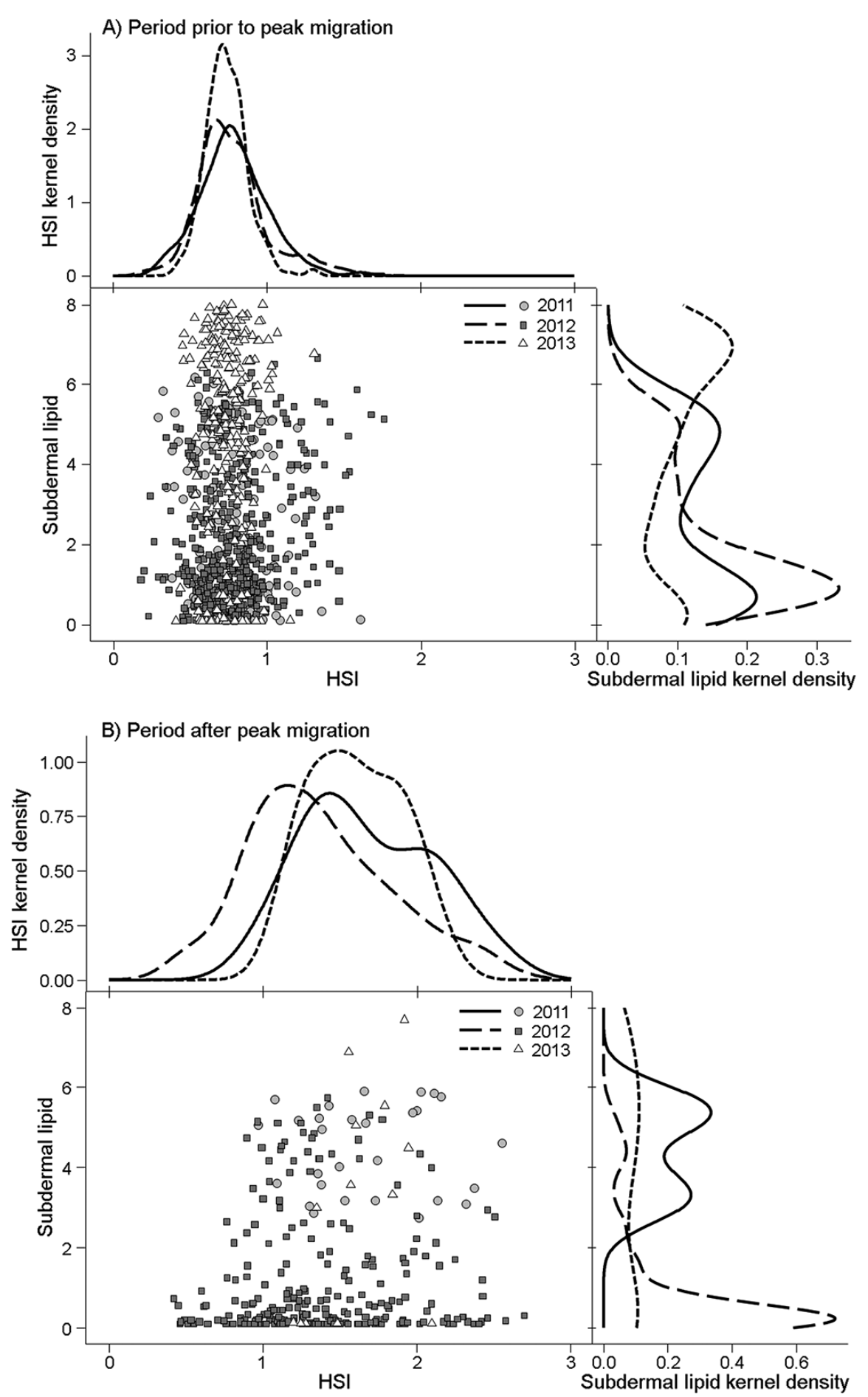

Fig. 3. Relative subdermal lipid estimates and hepatosomatic index (HSI) values for individual summer flounder Paralichthys dentatus collected (A) prior to peak migration in November (July to October) and (B) after peak migration (December to March). Symbols and lines indicate year classes: 2011 (circle, solid line), 2012 (square, long-dashed line), 2013 (triangle, shortdashed line). Kernel density plots aid in highlighting the prominent shift in the proportion of summer flounder above 1.5 HSI units in the time period after peak migration, as well as differences in the degree of subdermal lipid storage among year classes of the most robust individuals (highest mean $K_{i}$ Fig. 4). There were no significant differences in HSI among year classes of summer flounder (Fig. 4). Regardless of year, local density had a significant positive effect on $K$ (Table 2), indicating that the most robust individuals were collected at times when flounder aggregate. Temporal patterns in subdermal lipids were influenced by the significant interaction between local density and year class (Table 3 ). The data also suggest that a weak yearclass-density interaction may be present for HSI, although the interaction was not statistically significant at $\alpha=$ 0.05 (Table 3). Year-class specific models used to investigate the effect of local density on subdermal lipids and HSI indicated that, for the abundant 2012 year class, local density had a significant negative effect on subdermal lipids (Table 3) and a significant positive effect on HSI (Table 3). No effect of local density was detected on subdermal lipids or HSI for low-abundance (2011) and near-average (2013) year classes of juvenile summer flounder.

In general, the effects of year class and local density on mean condition of Atlantic croaker exhibited a pattern unlike that observed for summer flounder (Fig. 4, Tables 2 \& 3). The highly abundant 2012 year class exhibited the highest mean condition as measured by Fulton's $K$ and subdermal lipid (Fig. 4), but individuals in the low-abundance 2011 year class exhibited a similar degree of subdermal lipid storage as the 2012 year class. The 2013 year class exhibited the highest HSI values, but these were not significantly different from HSI values for the 2011 year class. We did not detect an effect of local density on mean condition of juvenile Atlantic croaker for any year class, whether by the full model (Fulton's $K$ and HSI; Table 2) or year-class specific models (subdermal lipids; Table 3); year-class specific models were examined for Atlantic croaker subdermal lipids due to a significant interaction between year class and local density (Table 3 ). 

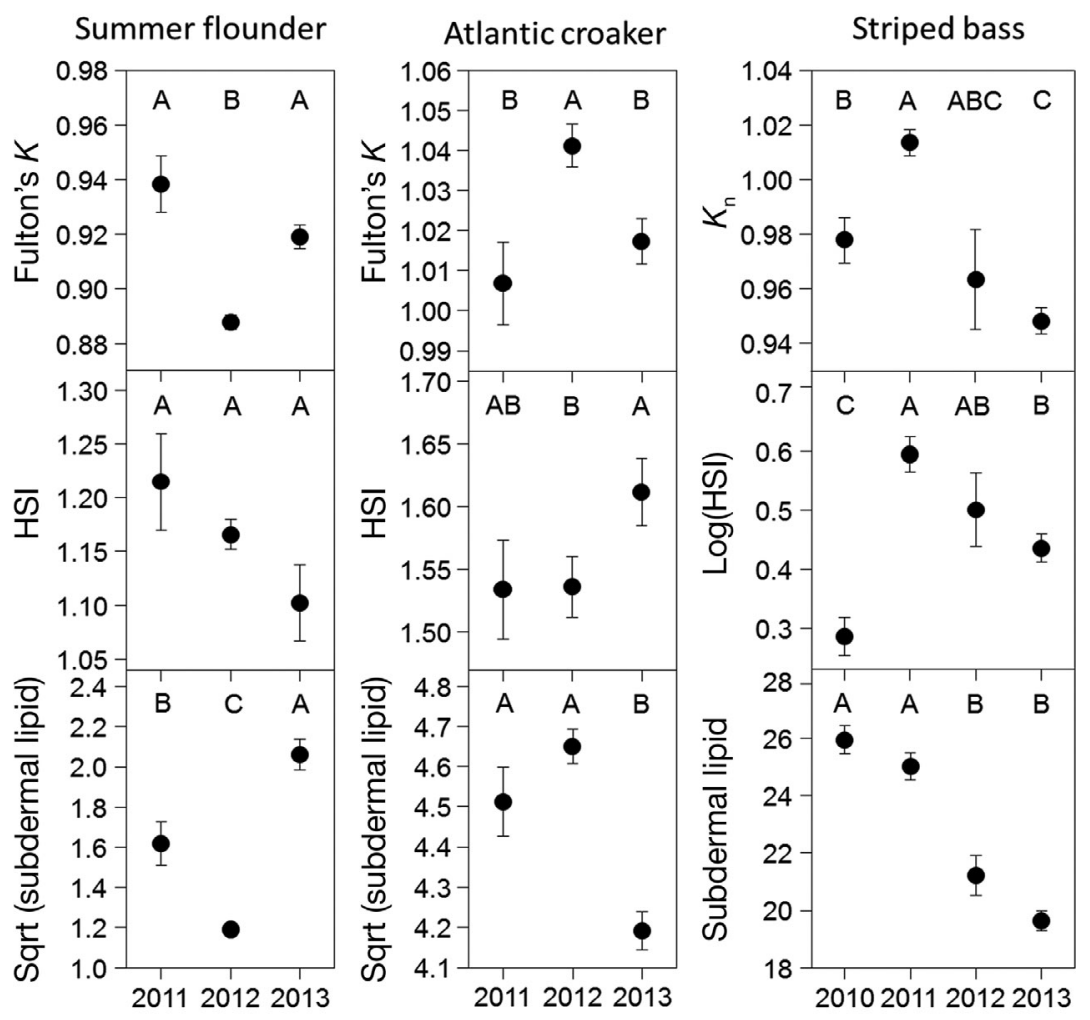

Fig. 4. Mean condition $( \pm \mathrm{SE})$ for year classes of juvenile summer flounder Paralichthys dentatus, Atlantic croaker Micropogonias undulatus, and striped bass Morone saxatilis adjusted for month of capture and local density by general linear mixed models. Condition was measured by length-based indices (Fulton's $K$ or relative condition $\left.\left[K_{\mathrm{n}}\right]\right)$, the hepatosomatic index (HSI), and relative subdermal lipid estimates. Letters indicate significantly different condition indices among year classes determined at $\alpha=0.05$. Sqrt designates a square-root transformation

Table 2. Factors influencing mean condition of juvenile summer flounder Paralichthys dentatus, Atlantic croaker Micropogonias undulatus, and striped bass Morone saxatilis determined by general linear mixed models for condition indices that were not influenced by the interaction between year class and density. Condition was measured by length-based indices (Fulton's $K$ or relative condition $\left[K_{n}\right]$ ), the hepatosomatic index (HSI), and relative subdermal lipid estimates. Significant density effects $(\mathrm{p}<0.05)$ are highlighted in bold, the effect of year class is shown in Fig. 4, and the effect of month is summarized via time periods in Table 1. 'na' indicates density was not applicable to the final model for estimating mean condition

\begin{tabular}{|c|c|c|c|c|c|c|c|c|c|c|c|}
\hline \multirow{2}{*}{ Species } & \multirow{2}{*}{ Condition index } & \multicolumn{3}{|c|}{ _ Year class } & \multicolumn{3}{|c|}{ - Month } & \multicolumn{4}{|c|}{-Density _- } \\
\hline & & $F$ & df & $\mathrm{p}$ & $F$ & df & $\mathrm{p}$ & Effect $(\gamma)$ & $F$ & df & $\mathrm{p}$ \\
\hline Summer flounder & Fulton's $K$ & 36.8 & 2,353 & $<0.01$ & 34.8 & 11,1704 & $<0.01$ & 0.87 & 48.6 & 1,1733 & $<0.01$ \\
\hline \multirow[t]{2}{*}{ Atlantic croaker } & Fulton's $K$ & 45.0 & 2,585 & $<0.01$ & 20.7 & 11,2591 & $<0.01$ & na & na & na & na \\
\hline & HSI & 17.0 & 2,571 & $<0.01$ & 50.8 & 11,321 & $<0.01$ & na & na & na & na \\
\hline \multirow[t]{3}{*}{ Striped bass } & $K_{\mathrm{n}}$ & 61.9 & 3,13 & $<0.01$ & 13.1 & 8,508 & $<0.01$ & -0.40 & 5.6 & 1,764 & 0.02 \\
\hline & HSI & 28.4 & 3,213 & $<0.01$ & 16.6 & 8,360 & $<0.01$ & na & na & na & na \\
\hline & Subdermal lipids & 94.3 & 3,576 & $<0.01$ & 16.9 & 8,707 & $<0.01$ & -46.66 & 14.2 & 1,212 & $<0.01$ \\
\hline
\end{tabular}

Table 3. Influence of local density on mean condition of juvenile summer flounder Paralichthys dentatus and Atlantic croaker Micropogonias undulatus for condition indices (HSI: hepatosomatic index) that were examined with year-specific models due to the potential influence of an interaction between year class and density. Significant density effects $(p<0.05)$ are in bold

\begin{tabular}{|c|c|c|c|c|c|c|c|c|c|c|c|c|c|c|c|c|}
\hline \multirow{2}{*}{ Species } & \multirow{2}{*}{$\begin{array}{l}\text { Condition } \\
\text { index }\end{array}$} & \multirow{2}{*}{\multicolumn{3}{|c|}{$\begin{array}{l}\text { Year class-density } \\
\text { interaction }\end{array}$}} & \multicolumn{4}{|c|}{$2011-$} & \multicolumn{4}{|c|}{2012} & \multirow[b]{2}{*}{$\begin{array}{c}\text { Effect } \\
\qquad(\gamma)\end{array}$} & \multicolumn{2}{|c|}{-2013} & \multirow[b]{2}{*}{$\mathrm{p}$} \\
\hline & & & & & $\begin{array}{l}\text { Effect } \\
(\gamma)\end{array}$ & $t$ & df & $\mathrm{p}$ & $\begin{array}{c}\text { Effect } \\
(\gamma)\end{array}$ & t $t$ & df & $\mathrm{p}$ & & $t$ & $\mathrm{df}$ & \\
\hline \multirow{2}{*}{$\begin{array}{l}\text { Summer } \\
\text { flounder }\end{array}$} & HSI & 2.5 & 2,1406 & 0.09 & 4.18 & 0.8 & 170 & 0.42 & 2.88 & 4.6 & 795 & $<0.01$ & -3.49 & -1.3 & 328 & 0.20 \\
\hline & $\begin{array}{l}\text { Subdermal } \\
\text { lipids }\end{array}$ & 5.4 & 2,1748 & $<0.01$ & -14.6 & -1.7 & 193 & 0.09 & -6.3 & -4.6 & 836 & $<0.01$ & 6.2 & 0.5 & 411 & 0.63 \\
\hline $\begin{array}{l}\text { Atlantic } \\
\text { croaker }\end{array}$ & $\begin{array}{l}\text { Subdermal } \\
\text { lipids }\end{array}$ & 5.3 & 2,1014 & $<0.01$ & 0.37 & 0.8 & 116 & 0.42 & 0.17 & 1.4 & 2526 & 0.15 & 0.38 & 1.2 & 1192 & 0.23 \\
\hline
\end{tabular}


Condition indices for juvenile striped bass varied by year class and density of conspecifics at the sampling site. The highly abundant 2011 year class exhibited high mean condition, regardless of the index examined (Fig. 4). Due to the low number of individuals collected in 2012, we did not detect significant differences in mean relative condition and HSI between the 2011 and 2012 year classes. The nearaverage 2010 year class of striped bass exhibited a similar degree of subdermal lipid storage as in 2011, but significantly lower mean HSI values than all other year classes (Fig. 4). The near-average 2013 year class exhibited low relative condition and subdermal lipid storage, but moderate HSI values. For all year classes, local density had a significant negative effect on $K_{\mathrm{n}}$ and subdermal lipids (Table 2), suggesting that for a given year class, local density affected condition of individual juvenile striped bass.

\section{DISCUSSION}

Temporal patterns in mean length-based indices $(K$ and $K_{\mathrm{n}}$ ), HSI, and subdermal lipids were apparent for juvenile summer flounder, Atlantic croaker, and striped bass, but the dynamics of these indices were not congruent. Inter-annual differences in mean condition were also not consistent among condition indices. The dissimilar patterns among condition indices indicate that allocation of energy to different tissues varies within and among years, potentially due to the influence of environmental conditions (e.g. prey availability) and local density. Therefore, the use of multiple indices may provide a more complete understanding of the energy-storage strategies used by juvenile fishes during the time they reside in estuarine nursery areas. By using multiple indices, we describe condition dynamics that suggest the accumulation of subdermal lipids occurs prior to peak migration for species that emigrate from Chesapeake Bay in the fall, as evident in juvenile summer flounder and Atlantic croaker. Liver lipid storage (increased HSI) may be an important survival strategy for estuarine residents during winter, potentially due to the role of the liver in lipid mobilization and transport (Sheridan 1988).

The association between life-history and energystorage strategies was particularly evident in the condition dynamics of the mid-Atlantic populations of summer flounder and Atlantic croaker. Large differences in mean condition indices were observed between the time periods prior to and after peak migration from Chesapeake Bay, with higher subdermal lipid content prior to the migration period and higher HSI values in the time period after peak migration. Interestingly, these species also display somewhat similar dynamics for some condition indices in the time period prior to peak migration. Atlantic croaker dramatically increase their subdermal lipid stores and relative weight throughout the spring and summer, prior to egress around September and October (Miller \& Able 2002). Patterns in the mean condition of summer flounder suggest a minor increase in subdermal lipid in October (prior to migration in the fall; Desfosse 1995), but a decline in relative weight. Both species exhibited low mean HSI values prior to migration, suggesting juveniles of these species may not use the liver to store fuel for migration. The majority of summer flounder and Atlantic croaker migrate to the continental shelf in the fall, but some members of these populations remain in Chesapeake Bay during winter. The condition dynamics we observed were influenced by the migration of individuals from these populations because we sampled juvenile fish from estuarine waters only, and did not sample fish from offshore environments. Thus, our winter samples from Chesapeake Bay reflect the condition of only the non-migratory individuals.

The increase in subdermal lipid stores observed prior to egress, particularly for juvenile Atlantic croaker, is consistent with the use of subdermal lipids to support migration (as seen in American shad; Leonard \& McCormick 1999). If subdermal lipids are also used by juvenile summer flounder to undertake coastal migrations in the late fall, then a portion of the juveniles from Chesapeake Bay may not have sufficient energy to complete these directed movements (e.g. the large proportion of low-lipid individuals observed in the 2012 year class; Fig. 3). Migration of juvenile summer flounder may also be supported by energy derived from other storage tissues or from protein. If summer flounder use lipids stored in the liver or protein to fuel migrations, then we would have expected HSI or length-based indices to increase in the period prior to migration. This was not observed, suggesting that juvenile summer flounder with insufficient subdermal lipid stores would have to obtain energy for migration en route, or remain in the estuary during winter. The availability of sufficient energy reserves prior to migration may have consequences for population productivity in summer flounder and Atlantic croaker because these species have the potential to mature at the end of their first year of life (6 to $40 \%$ of summer flounder, Morse 1981; > $85 \%$ of Atlantic croaker, Barbieri et al. 1994). 
All 3 species displayed elevated mean HSI values among individuals that resided in Virginia estuaries during winter, suggesting the use of a common energy-storage strategy during this time. Mean HSI values also increased throughout the winter period for juvenile summer flounder and striped bass, peaking in March. Peaks in the average lipid and energy content of juvenile striped bass have been observed as late as March in other studies as well (Hurst et al. 2000). Several explanations are consistent with the observed elevated mean HSI values for winter residents. Liver lipids may increase during winter as individuals remobilize lipids to the liver. Alternatively, HSI may increase due to a decline in body mass (via reduced protein and/or water mass) while liver mass is conserved. We do not expect that high HSI values for Atlantic croaker and summer flounder during the winter time period result from feeding because in a laboratory setting we observed high mean HSI values among individuals deprived of food for up to $14 \mathrm{wk}$ during winter (mean $=1.48$ units for Atlantic croaker and mean $=1.44$ units for summer flounder; R. W. Schloesser pers. obs.). An alternative explanation is differential mortality. Energy deficits combined with prey scarcity and other stressors associated with winter conditions (e.g. near-lethal temperatures, depressed osmoregulatory ability, and disease) may lead to increased mortality of individuals with insufficient lipid stores (Hurst et al. 2000). If individuals with low HSI values have higher mortality rates than conspecifics with high HSI levels, then we would expect to observe an increase in the average HSI of fish collected in winter from Chesapeake Bay. We also note that summer flounder with HSI values <1 were not observed after December, which is consistent with low HSI values being associated with higher mortality during winter. Although presented as alternatives, these explanations most likely act in combination.

The effects of local density on mean condition differed among the 3 species investigated. No significant effects of local density were detected on mean condition of Atlantic croaker, regardless of the index or year class examined, suggesting that for a given year class, condition is independent of density for this species. For striped bass, local density had a generally negative effect on mean condition as measured by $K_{\mathrm{n}}$ and subdermal lipid. Because higher densities of striped bass were observed during late winter (local density $=0.021$ ind. $\mathrm{m}^{-2}$ ), this result is consistent with food limitation during winter. Yet for summer flounder, there were positive influences of local density on mean $K$ in all years. We suspect this result is due to the high densities and high mean $K$ values of individuals observed in the time period after peak migration (local density $=0.013$ ind. $\mathrm{m}^{-2}$ ); these summer flounder were short for their body mass. Interestingly, local density had opposite effects on mean HSI and subdermal lipid for the 2012 year class of summer flounder. A greater number of summer flounder from the highly abundant 2012 year class resided in Chesapeake Bay during winter (compared with observations from 24 other year classes; authors' unpubl. data; also see Fig. 3). We speculate that high densities of the 2012 year class resulted in a greater proportion of individuals that failed to build subdermal lipid stores prior to the period of migration (a negative effect of density on mean subdermal lipids), resulting in a greater proportion of individuals that stored lipids in the liver for winter (a positive effect of density on mean HSI). Indeed, a larger number of individuals with low subdermal lipids and high HSI values were observed in winter of 2012 than in any other year (Fig. 3). From these results, we hypothesize that summer flounder in Chesapeake Bay exhibit condition-dependent partial migration-a phenomenon observed in cyprinids whereby healthier fish migrate away from sub-optimal conditions in higher proportion and earlier than poor-conditioned conspecifics (Brodersen et al. 2008). Mortality risks of migrants may decrease because migrants avoid unsuitable environmental conditions (Brodersen et al. 2008). Individuals that moved out of Chesapeake Bay were not available to our sampling program for condition assessment, and thus no direct comparison could be made between out-migrants and winter residents. Such a comparison of residents and migrants would be necessary to test the condition-dependent partial-migration hypothesis for summer flounder.

For a given index, inter-annual differences in mean condition were apparent for juvenile summer flounder, Atlantic croaker, and striped bass, but the potential for inter-annual variation in condition to influence survival and year-class strength may differ for these species. High mortality of poor-condition individuals may be of particular concern for juvenile summer flounder. The most abundant year class of summer flounder (2012) had the lowest mean condition and displayed a higher degree of winter residency. Juvenile summer flounder that reside in mid-Atlantic estuaries during winter may be more likely to succumb to mortality because of a parasitic flagellate, Trypanoplasma bullocki, common to this species during winter (Burreson 1982). Mortality of fish infected with the flagellate approaches $100 \%$ when water temperatures are below $5^{\circ} \mathrm{C}$ (Burreson 1982). Conversely, condition-dependent mortality and its influence on 
year-class strength may be of lower concern for juvenile Atlantic croaker. The abundant 2012 year class of Atlantic croaker was comprised of well-conditioned individuals, and mean condition was not influenced by local density. This suggests that in some years, habitats in the mid-Atlantic region may have sufficient prey resources to support a healthy population of juvenile Atlantic croaker despite high abundances. Similarly, the 2011 year class of striped bass exhibited high abundance; although local density negatively affected condition, mean condition of striped bass in Virginia estuaries was high in 2011. One interpretation of this finding may be that a sufficient quantity of suitable habitat was available in 2011 to result in relatively low local densities of striped bass, even though a strong year class was produced. Therefore, condition may influence year-class strength of striped bass if the availability of suitable habitat is limited during years of high abundance, but additional year classes of striped bass would need to be examined to investigate this hypothesis. The relationships among yearclass strength, local density, and juvenile fish condition requires further examination in the light of variable prey and habitat resources to elucidate the mechanisms that underlie the observed effects of local density on condition among years.

Assessments of energy content during critical periods in the life cycle are essential for understanding the population dynamics of coastal species (Rosa et al. 2010), and particular condition indices may be useful for assessing energy content during these critical periods. For example, we recommend examining subdermal lipids relative to the time period of migration, particularly for species such as summer flounder and Atlantic croaker, and recommend the use of HSI for assessing the condition of juvenile fishes that reside in estuarine habitats during winter. However, the temporal dynamics of multiple condition indices would need to be considered to fully understand the energy-storage strategies used by juvenile fishes, particularly for species with unique life histories. Annual assessments of mean condition may improve our understanding of variability in year-class strength, particularly in the presence of density-dependent effects, but the methods used to assess condition must be selected carefully to ensure that they are appropriate for the species and time period of interest.

Acknowledgements. This project would not have been possible without the help of many individuals who collected specimens, particularly the staff of the VIMS Recruitment Program (H. Brooks, A. Comer, J. Conwell, W. Lowery, L. Machut, L. Nys, R. Norris, T. Tuckey). A special thanks to L.
Nys for her assistance in measuring condition of these specimens. We thank 3 anonymous reviewers for providing comments that helped to clarify this presentation. Virginia Sea Grant, the Virginia Marine Resources Commission, and the VIMS Ziegler Fellowship provided funds to support this research. This paper is Contribution No. 3577 of the Virginia Institute of Marine Science, The College of William \& Mary.

\section{LITERATURE CITED}

Able KW, Fahay MP (2010) Ecology of estuarine fishes: temperate waters of the western North Atlantic. John Hopkins University Press, Baltimore, MD

- Adams SM, McLean RB (1985) Estimation of largemouth bass, Micropterus salmoides Lacèpede, growth using liver somatic index and physiological variables. J Fish Biol 26:111-126

Anderson RO, Neumann RM (1996) Length, weight, and associated structural indices. In: Murphy BR, Willis DW (eds) Fisheries techniques, 2nd edn. American Fisheries Society, Bethesda, MD, p 447-482

Anonymous (2010) User manual, Distell fish fatmeter model FFM-992 and model FFM-692. Distell.com, Fauldhouse

Barbieri LR, Chittenden ME Jr, Lowerre-Barbieri SK (1994) Maturity, spawning, and ovarian cycle of Atlantic croaker, Micropogonias undulatus, in the Chesapeake Bay and adjacent coastal waters. Fish Bull 92:671-685

Booth D, Alquezar R (2002) Food supplementation increases larval growth, condition and survival of Acanthochromis polyacanthus. J Fish Biol 60:1126-1133

Brodersen J, Nilsson PA, Hansson LA, Skov C, Brönmark C (2008) Condition-dependent individual decision-making determines cyprinid partial migration. Ecology 89: 1195-1200

Burnham KP, Anderson DR (2002) Model selection and multimodel inference: a practical information-theoretic approach, 2nd edn. Springer, New York, NY

Burreson EM (1982) Trypanoplasmiasis in flounder along the Atlantic coast of the United States. In: Anderson DP, Dorson M, Dubourget P (eds) Antigens of fish pathogens. Collection Foundation Marcel Merieux, Lyon, p 251-260

Casini M, Cardinale M, Hjelm J (2006) Inter-annual variation in herring, Clupea harengus, and sprat, Sprattus sprattus, condition in the central Baltic Sea: What gives the tune? Oikos 112:638-650

- Crossin GT, Hinch SG (2005) A nonlethal, rapid method for assessing the somatic energy content of migrating adult Pacific salmon. Trans Am Fish Soc 134:184-191

Desfosse JC (1995) Movements and ecology of summer flounder, Paralichthys dentatus, tagged in the southern mid-Atlantic bight. PhD dissertation, College of William \& Mary, Williamsburg, VA

Fogarty MJ, Sissenwine MP, Cohen EB (1991) Recruitment variability and the dynamics of exploited marine populations. Trends Ecol Evol 6:241-246

Froese R (2006) Cube law, condition factor and weightlength relationships: history, meta-analysis and recommendations. J Appl Ichthyol 22:241-253

> Gardiner WR, Geddes P (1980) The influence of body composition on the survival of juvenile salmon. Hydrobiologia 69:67-72

> Houde ED (1997) Patterns and trends in larval-stage growth and mortality of teleost fish. J Fish Biol 51:52-83

Houde ED (2009) Recruitment variability. In: Jakobsen T, 
Fogarty M, Megrey B, Moksness E (eds) Reproductive biology of fishes: implications for assessment and management. Wiley-Blackwell, Oxford, p 91-171

Hurst TP, Conover DO (1998) Winter mortality of young-ofthe-year Hudson River striped bass (Morone saxatilis): size-dependent patterns and effects on recruitment. Can J Fish Aquat Sci 55:1122-1130

> Hurst TP, Conover DO (2003) Seasonal and interannual variation in the allometry of energy allocation in juvenile striped bass. Ecology 84:3360-3369

Hurst TP, Schultz ET, Conover DO (2000) Seasonal energy dynamics of young-of-the-year Hudson River striped bass. Trans Am Fish Soc 129:145-157

> Jensen AJ (1979) Energy content analysis from weight and liver index measurements of immature pollock (Pollachius virens). J Fish Res Board Can 36:1207-1213

Jobling M (1994) Fish bioenergetics. Chapman \& Hall, London

> Jonsson B, Jonsson N (1993) Partial migration: niche shift versus sexual maturation in fishes. Rev Fish Biol Fish 3: 348-365

Kent M (1990) Hand-held instrument for fat/water determination in whole fish. Food Contr 1:47-53

Kenward MG, Roger JH (1997) Small sample inference for fixed effects from restricted maximum likelihood. Biometrics 53:983-997

Kerr LA, Secor DH (2009) Bioenergetic trajectories underlying partial migration in Patuxent River (Chesapeake Bay) white perch (Morone americana). Can J Fish Aquat Sci 66:602-612

Kerr LA, Secor DH, Piccoli PM (2009) Partial migration of fishes as exemplified by the estuarine-dependent white perch. Fisheries (Bethesda, MD) 34:114-123

Kraus RT, Musick JA (2001) A brief interpretation of summer flounder, Paralichthys dentatus, movements and stock structure with new tagging data on juveniles. Mar Fish Rev 63:1-6

- Lambert Y, Dutil JD (1997) Can simple condition indices be used to monitor and quantify seasonal changes in the energy reserves of Atlantic cod (Gadus morhua)? Can J Fish Aquat Sci 54:104-112

> Le Cren ED (1951) The length-weight relationship and seasonal cycle in gonad weight and condition in the perch (Perca fluviatilis). J Anim Ecol 20:201-219

> Leonard JBK, McCormick SD (1999) Effects of migration distance on whole-body and tissue-specific energy use in American shad (Alosa sapidissima). Can J Fish Aquat Sci 56:1159-1171

Littell RC, Stroup WW, Freund RJ (2002) SAS for linear models, 4th edn. SAS Institute, Cary, NC

Littell RC, Milliken G, Stroup WW, Wolfinger R, Schabenberger O (2006) SAS for mixed models, 2nd edn. SAS Institute, Cary, NC

Lochmann SE, Maillet GL, Frank KT, Taggart CT (1995) Lipid class composition as a measure of nutritional condition in individual larval Atlantic cod (Gadus morhua). Can J Fish Aquat Sci 52:1294-1306

Machut LS, Fabrizio MC (2012) Estimation of juvenile striped bass relative abundance in the Virginia portion of Chesapeake Bay. Annual report to the Virginia Marine Resources Commission. Virginia Institute of Marine Science, Gloucester Point, VA

Miller MJ, Able KW (2002) Movements and growth of

Editorial responsibility: Jana Davis,

Annapolis, Maryland, USA tagged young-of-the-year Atlantic croaker (Micropogonias undulatus L.) in restored and reference marsh creeks in Delaware Bay, USA. J Exp Mar Biol Ecol 267:15-33

Miller MJ, Nemerson DM, Able KW (2003) Seasonal distribution, abundance, and growth of young-of-the-year Atlantic croaker (Micropogonias undulatus) in Delaware Bay and adjacent marshes. Fish Bull 101:100-115

Mittelbach GG (1988) Competition among refuging sunfishes and effects of fish density on littoral zone invertebrates. Ecology 69:614-623

Morse WW (1981) Reproduction of the summer flounder, Paralichthys dentatus (L). J Fish Biol 19:189-203

$>$ Newsome GE, Leduc G (1975) Seasonal changes of fat content in the yellow perch (Perca flavescens) of two Laurentian lakes. J Fish Res Board Can 32:2214-2221

R Core Team (2014) R: a language and environment for statistical computing. R Foundation for Statistical Computing, Vienna

Ricker WE (1975) Computation and interpretation of biological statistics of fish populations. Bull Fish Res Board Can 191:1-382

Rios FS, Carvalho CS, Pinheiro GHD, Donatti L, Fernandes MN, Rantin FT (2011) Utilization of endogenous reserves and effects of starvation on the health of Prochilodus lineatus (Prochilodontidae). Environ Biol Fishes 91:87-94

Rosa R, Gonzalez L, Broitman BR, Garrido S, Miguel A, Santos P, Nunes ML (2010) Bioenergetics of small pelagic fishes in upwelling systems: relationship between fish condition, coastal ecosystem dynamics and fisheries. Mar Ecol Prog Ser 410:205-218

Schloesser RW (2015) Condition of juvenile fishes in estuarine nursery areas: measuring performance and assessing temporal and spatial dynamics with multiple indices. PhD dissertation, College of William \& Mary, Williamsburg, VA

Sheridan MA (1988) Lipid dynamics in fish: aspects of absorption, transportation, deposition and mobilization. Comp Biochem Physiol B 90:679-690

Simpkins DG, Hubert WA, Del Rio CM, Rule DC (2003) Physiological responses of juvenile rainbow trout fasting and swimming activity: effects on body composition and condition indices. Trans Am Fish Soc 132:576-589

Sissenwine MP (1984) Why do fish populations vary? In: May RM (ed) Exploitation of marine communities. Springer, New York, NY, p 59-94

Sogard SM, Spencer ML (2004) Energy allocation in juvenile sablefish: effects of temperature, ration and body size. J Fish Biol 64:726-738

Thompson JM, Bergersen EP, Carlson CA, Kaeding LR (1991) Role of size, condition, and lipid content in the overwinter survival of age-0 Colorado squawfish. Trans Am Fish Soc 120:346-353

Tuckey TD, Fabrizio MC (2015) Estimating relative juvenile abundance of ecologically important finfish in the Virginia portion of the Chesapeake Bay, Project \# F-104$\mathrm{R}-19$. Annual report to the Virginia Marine Resources Commission. Virginia Institute of Marine Science, Gloucester Point, VA

Wicker AM, Johnson WE (1987) Relationships among fat content, condition factor, and first-year survival of Florida largemouth bass. Trans Am Fish Soc 116:264-271

Zuur A, Ieno EN, Smith GM (2007) Analysing ecological data. Springer, New York, NY

Submitted: March 10, 2015; Accepted: August 3, 2016

Proofs received from author(s): September 12, 2016 